\title{
IMPACT OF SPRAYING WITH POTASSIUM, ZINC AND ARTEMISIA INCULTA EXTRACT ON FLOWERING, SETTING AND ANATOMICAL FEATURE OF Vicia Faba, L. PLANTS
}

\author{
ALI, T.B. ${ }^{1}$, G.S.A. EISA ${ }^{2}$ AND A. A. KHALAFALLAH ${ }^{3}$
}

1. Veg. Res. Dept., Hort. Res. Inst., Agric. Res. Center

2. Agric. Botany and Plant Path. Department, Faculty of Agriculture, Zagazig

University, Zagazig, Egypt.

3. Botany Depart. Womens College for Arts, Science and Education, Ain Shams Univ.

(Manuscript received 1 Aprils 2009)

\begin{abstract}
This investigation was carried out during the two successive seasons of 2006 - 2007 and 2007 - 2008 on Vicia faba, L. cv. Kassasin 1. The aim was to study the effect of spraying with potassium at rates 0.3 and $0.6 \% \mathrm{~K}_{2} \mathrm{O}$, zinc at rates 100 and 200 ppm and Artemisia inculta extract at rates 5 and $10 \mathrm{~cm}^{3} / \mathrm{l}$ as well as different combination treatments among them at vegetative growth and flowers initiation on growth, flowering, yield and its components and some anatomical feature. Plants were sprayed three times at 30, 45 and 60 days after sowing.

All spraying materials showed a significant increase in plant growth, flowering, setting, quantity and quality of yield and anatomical structure as compared to untreated check.

Spraying plants with Artemisia inculta extract at rate 5 or 10 $\mathrm{cm}^{3} / /$ led to improve plant height, number of leaves and branches/plant and dry matter/plant, flowering, setting and yield and its components (pod length, pod weight, number of pods/plant and pod yield/fed) more than spraying with potassium and zinc. Meanwhile, potassium effect had uppermost improving zinc effect on characters under study. As for the effect of spraying materials on anatomical structure of stem and leaf, results indicated positive effects with all the studied characters of plant organs.

In general, spraying Vicia faba, L. plants with combination of potassium, zinc and Artemisia inculta extract at all different concentrations showed significantly increase on plant growth, flowering, setting, yield quantity and quality and anatomical structure than spray with them alone or control.
\end{abstract}

\section{INTRODUCTION}

Vicia faba, L. is one of the principal winter Fabaceae crops in Egypt as a source of protein in food. It can be able to utilize atmospheric nitrogen in a process called nitrogen fixation via rhizobium bacteria. It is mainly cultivated for local consumption, since, pods harvested either at green pod stage for fresh market or at mature stage for dry seeds. Vicia faba, L. plants produce numerous flowers, but the most of them are dropping. There are many factors affect on flowering and flowers setting 
percentage. Great attention has been focused on the possibility of using natural and safety substances, i.e. potassium, zinc and Artemisia inculta extract in order to improve growth and yield.

Potassium is one of the essential nutrients needed by the plants and plays a highly recognized role in plant life. Moreover such nutrient improves the quantity and quality of pods (Abd Allatif et al., 2002).

Micro-nutrients play an important role in plant metabolism. The role of zinc as a micro-element has been reported by many researchers. Zinc is known to be required for a variety of metabolic processes in plants such as photosynthetic reactions, nucleic acids metabolism, proteins and carbohydrates biosynthesis and starch metabolism (Srivastava et al., 1997). Zinc is necessary for the synthesis of tryptophan and hence indirectly for the synthesis of auxin. The activities of a number of respiratory enzymes, the accumulation of quinines and catechol aggregates, respiratory impairment, changes in the levels of proteins and amino acids have been reported to follow restrictions in the zinc supply (Klein et al., 1962). It is well known, that zinc positively affects cell division and expansion. Moreover, zinc was found to ameliorate plant growth under saline soils (Shukla and Mukhi, 1985).

The positive effects of zinc on the growth and yield have been observed by many investigators such as Agwah and Mahmoud (1994) and Agwah and Mahmoud (1994), on tomato and Fayza et al. (2007) on pepper plants, found that spraying plants with Zn solution significantly increased fruit setting and early and total yield.

Water extracts of the flowering tops and leaves of Artemisia plants have many antioxidants, some organic acid such as artemisinic acid and essential oils such as artemisinin oil (Shi et al.,1999 and Gascon et al.,1999). Sukul et al. (1999) found that sprayed Vigna unguiculata with extracts of the flowering tops and leaves of Artemisia maritima improved growth in terms of shoot length, shoot weight, root length and number of bacterial nodules.

Spraying plants with antioxidants have a positive effect on plant growth, yield quantity and quality, stimulate nutrient absorption and to overcome the harmful effect of some environmental stresses on plant growth (Abd El-Naem, 2005).

The present study was undertaken to evaluate the effect of spraying with some materials (potassium, zinc and Artemisia inculta extract) which will be considered an attempt to improve flowering and flowers setting percentage, which reflect on yield quantity and quality of Vicia faba, L. cv. Kassasin 1. . 


\section{MATERIALS AND METHODS}

Two field experiments were carried out during the two successive seasons of 2006 - 2007 and 2007 - 2008 at the Experimental Farm of El-Kassasin Horticultural Research Station, Ismailia Governorate, to study the effect of spraying with potassium, zinc, Artemisia inculta extract and different combination among them on growth, flowering, setting and anatomical feature of Vicia faba, L. cv. Kassasin 1. The soil of the Experimental field was sandy in texture, the physical and chemical analyses of soil are shown in Table (1).

Table 1. Physical and chemical analysis of the experimental soil.

\begin{tabular}{|c|c|c|c|}
\hline Sand \% & $88 . .24$ & $\mathrm{HCO}_{3}^{-}$ & 1.00 \\
Silt \% & 4.25 & $\mathrm{Cl}^{-}$ & 0.50 \\
Clay \% & 7.51 & $\mathrm{SO}_{4}^{--}$ & 0.97 \\
Soil texture & sandy & Macro-elements (ppm) & \\
F.C. \% & 11.21 & $\mathrm{~N}$ & 81 \\
W.P. \% & 2.24 & $\mathrm{P}$ & 23 \\
Organic matter \% & 0.44 & $\mathrm{~K}$ & 103 \\
pH & 8.1 & Micro-elements (ppm) & \\
E.C. (mmohs/cm) & 1.21 & $\mathrm{Fe}^{++}$ & 2.0 \\
$\mathrm{CaCO}$ & $\mathrm{Cu}^{++}$ & 0.16 \\
Soluble ions (meq/L) & 2.6 & $\mathrm{Zn}^{++}$ & 0.26 \\
$\mathrm{Ca}^{++}$ & 1.00 & $\mathrm{Mn}^{++}$ & 0.80 \\
$\mathrm{Mg}^{++}$ & 0.40 & & \\
$\mathrm{Na}^{+}$ & 0.76 & & \\
$\mathrm{~K}^{+}$ & 0.31 & & \\
\hline
\end{tabular}

Seeds were sown in hills ( 2 seeds/hill) in two sides of line as $20 \mathrm{~cm}$ apart on $19^{\text {th }}$ and $24^{\text {th }}$ October in 2005 and 2006 seasons, respectively. The experiment included 15 treatments as follows:

1. Control (sprayed water).

2. Sprayed with zinc at rate $100 \mathrm{ppm}$.

3. Sprayed with zinc at rate $200 \mathrm{ppm}$.

4. Sprayed with Artemisia inculta extract at rate $5 \mathrm{~cm}^{3} /$ liter.

5. Sprayed with Artemisia inculta extract at rate $10 \mathrm{~cm}^{3} /$ liter.

6. Sprayed with $\mathrm{K}_{2} \mathrm{O}$ at rate $0.3 \%$.

7. Sprayed with $\mathrm{K}_{2} \mathrm{O}$ at rate $0.6 \%$.

8. Sprayed with $100 \mathrm{ppm}$ zinc $+0.3 \% \mathrm{~K}_{2} \mathrm{O}+5 \mathrm{~cm}^{3}$ Artemisia inculta extract/liter.

9. Sprayed with $100 \mathrm{ppm}$ zinc $+0.3 \% \mathrm{~K}_{2} \mathrm{O}+10 \mathrm{~cm}^{3}$ Artemisia inculta extract/liter.

10. Sprayed with $100 \mathrm{ppm}$ zinc $+0.6 \% \mathrm{~K}_{2} \mathrm{O}+5 \mathrm{~cm}^{3}$ Artemisia inculta extract/liter.

11. Sprayed with $100 \mathrm{ppm}$ zinc $+0.6 \% \mathrm{~K}_{2} \mathrm{O}+10 \mathrm{~cm}^{3}$ Artemisia inculta extract/liter.

12. Sprayed with $200 \mathrm{ppm}$ zinc $+0.3 \% \mathrm{~K}_{2} \mathrm{O}+5 \mathrm{~cm}^{3}$ Artemisia inculta extract/liter.

13. Sprayed with $200 \mathrm{ppm}$ zinc $+0.3 \% \mathrm{~K}_{2} \mathrm{O}+10 \mathrm{~cm}^{3}$ Artemisia inculta extract/liter.

14. Sprayed with $200 \mathrm{ppm}$ zinc $+0.6 \% \mathrm{~K}_{2} \mathrm{O}+5 \mathrm{~cm}^{3}$ Artemisia inculta extract/liter.

15. Sprayed with $200 \mathrm{ppm}$ zinc $+0.6 \% \mathrm{~K}_{2} \mathrm{O}+10 \mathrm{~cm}^{3}$ Artemisia inculta extract/liter. 
Vine Artemisia inculta were finely ground and soaked for 24 hours in water at rate $1 \mathrm{~km} / 10$ liter water then filtrate extract for using.

These treatments arranged in a complete randomized block design with three replications. The experimental unit area was $21 \mathrm{~m}^{2}(4.2 \times 5 \mathrm{~m})$ and each unit contained six rows with $5 \mathrm{~m}$ length for each and $70 \mathrm{~cm}$ width of them, four inner rows were possessed for yield determination, whereas the two outer rows were for determination of plant growth characters. One row was left between two experimental plots to avoid the overlapping. Plants were sprayed three times at age 30, 45 and 60 days after sowing, the normal agricultural practices of Vicia faba, L. production under drip irrigation system of this area were followed according to the recommendations of Agriculture Ministry.

\section{Data recorded}

\section{A. Plant Growth}

A random sample of six plants from each plot was taken at flowering stage (60 days) and the following data were recorded plant height $(\mathrm{cm})$, number of leaves/plant, number of branches/plant, Dry weight of whole plant (gm):

A random sample of other six plants from each plot was taken and dried at $70^{\circ} \mathrm{C}$ till constant weight and the dry weight of whole plant was determined

\section{B. Green Pods Yield and Quality}

Mature green pods were continuously harvested when reached suitable maturity stages. The following data were recorded:

1. Average pod length $(\mathrm{cm})$.

2. Average pod weight (gm).

3. Number of green pods/plant $=\frac{\text { Total number of green pods } / \text { plot }}{\text { Number of plants/plot }}$

4. Green pods yield

Total green pods yield (tons/fed) was calculated on the base of total yield along harvesting stages by summing (the sum of all harvests).

\section{Flowering and setting characters}

A random sample of five plants from each plot were labeled and the following data were recorded

1. Number of flowers/plant.

2. Setting percentage $=$ Total number of green pods/plant $\times 100$ Total number of flowers/plant

3. Height of $1^{\text {st }}$ pod on the main stem $(\mathrm{cm})$.

4. Net weight of seeds percentage $=$ Total weight of green seeds $X 100$

5. Number of seeds/pod. Total weight of green pods 


\section{Anatomical study}

Specimens of selected treatments at the age of 120 days from the middle part of the $6^{\text {th }}$ internode and its leaf from apex of the Vicia faba, L. plants were made in sections as described by Willy (1971). The sections were photographed by using light microscope (Olympus) with digital camera (Canon Power Shot S80) connected to computer, the photographs were taken by Zoom Browser Ex program. The dimensions of stems and leaves sections were measured by using Corel Draw program ver. 11.

\section{Statistical analysis}

The obtained data subjected to statistical analysis according to statistical analysis of variance according to Snedecor and Cochran (1980) and the means separation were done according to Duncan (1958).

\section{RESULTS AND DISCUSSION}

\section{1- Vegetative Growth}

Results given in Table 2 show the effect of spraying with zinc, potassium, Artemisia inculta extract and different combination treatments among them as well as water spray (control) on plant height, number of leaves and branches/plant and dry matter of whole plant. It is obvious that vegetative growth (except number of branches/plant) was promoted with all spraying materials as compared to control (sprayed water). This may be due to potassium plays a highly recognized role in plant life (Abd Allatif et al., 2002) and zinc is known to be required for a variety of metabolic processes in plants such as photosynthetic reactions, nucleic acids metabolism, proteins and carbohydrates biosynthesis, starch metabolism, and necessary for the synthesis of tryptophan and hence indirectly for the synthesis of auxin (Klein et al., 1962).

Spraying plants with Artemisia inculta extract alone at all concentrations recorded the uppermost values of plant height, number of leaves/plant and dry matter of whole plant than spraying with zinc or potassium alone effect. Meanwhile, sprayed plants with potassium alone increased vegetative growth more than zinc alone. This may be due to that Artemisia plants extract have many antioxidants, some organic acid such as artemisinic acid and essential oils such as artemisinin oil (Shi et al., 1999 and Gascon et al., 1999). Sukul et al. (1999) found that sprayed Vigna unguiculata with extracts of the flowering tops and leaves of Artemisia maritima improved growth in terms of shoot length, shoot weight, root length and number of bacterial nodules. Also, antioxidants have positive effect on plant growth, stimulate nutrient absorption and to overcome the harmful effect of some environmental stresses on plant growth (Abd El-Naem, 2005).

In general, spraying Vicia faba, L. plants with combination of potassium, zinc and Artemisia inculta extract at all different concentration showed significantly 
increase on plant height, number of leaves/plant and dry matter/plant than spray with them alone or control.

\section{2- Pods physical characters and yield}

The effect of spraying with potassium, zinc, Artemisia inculta extract and different combination among them on pods physical characters and yield (pod length, pod weight, number of pods/plant and pods yield/fed) are shown in Table 3.

It is evident from the data that, sprayed plants with zinc did not reflect any significant effect on pod length, pod weight, number of pods/plant and pods yield/fed, this may be due to that plants received enough amounts of micro-elements from organic manure applied to soil. On the other hands, sprayed plants with Artemisia extract or potassium alone had a positive effect on pods physical characters and yield as compared to control. These results agree with those obtained by Abd Allatif et al. (2002) found that sprayed plants with potassium improves the quantity and quality of pods.

Sprayed with Artemisia extract alone caused a significant increase in pods physical characters and yield more than potassium effect. This may be due to Artemisia plants extract have many antioxidants which had a positive effect on yield quantity and quality, stimulate nutrient absorption and to overcome the harmful effect of some environmental stresses on plant growth (Abd El-Naem, 2005).

In general, the best treatment for increasing pods physical characters and yield was that of plants sprayed with combination of potassium, zinc and Artemisia inculta extract at different concentrations than those sprayed with individual treatments or control. This may be due to positive effect of potassium, zinc and Artemisia extract on physiological processes in plant which reflect on yield quality and quantity, and sprayed plants with mixed of them gave the maximum beneficial than each of them alone.

\section{3- Flowering, setting and yield quality characters}

Table 4 shows the effect of potassium, zinc, Artemisia inculta extract and different combination among them on number of flowers/plant, setting percentage, number of seeds/pod, net weight of seeds percentage and height of $1^{\text {st }}$ pod on main stem. It is clear from such data that all spraying materials showed a significant increase in number of flowers/plant, setting percentage, number of seeds/pod and net weight of seeds percentage. But they showed a significant decrease in height of $1^{\text {st }}$ pod on main stem as compared to control (sprayed water).

Results indicate that spraying plants three times with $200 \mathrm{ppm}$ zinc alone at age 30, 45 and 60 days after sowing significantly increased number of seeds/pod in first season only, but decreased height of $1^{\text {st }}$ pod on main stem more than control in both seasons of study. The presented results coincide with those reported by Agwah and Mahmoud (1994), on tomato and Fayza et al. (2007) on pepper plants, found that 
spraying plants with $\mathrm{Zn}$ solution significantly increased fruit setting and early and total yield.

Results indicate also that spraying plants three times with 5 or $10 \mathrm{~cm}^{3} /$ liter Artemisia extract alone caused a significant increase in setting percentage in both seasons and net weight of seeds percentage in second season only, meanwhile spraying plants with Artemisia extract significantly decreased height of $1^{\text {st }}$ pod on main stem more than potassium, zinc and control. These results agree with those obtained by Sukul et al. (1999).

Spraying Vicia faba, L. plants with 0.3 or $0.6 \% \mathrm{~K}_{2} \mathrm{O}$ alone at age 30,45 and 60 days showed a significant increase in net weight of seeds percentage, and showed a significant decrease in height of $1^{\text {st }}$ pod on main stem more than zinc, Artemisia extract and control. These results may be due to that potassium plays a highly recognized role in plant life. Moreover such nutrient improves the quantity and quality of pods (Abd Allatif et al., 2002).

Table also showed that, the best treatment for increasing number of flowers/plant, setting percentage, number of seeds/pod, net weight of seeds percentage and height of $1^{\text {st }}$ pod on main stem was sprayed plants with combination among of potassium, zinc and Artemisia inculta extract at different concentrations than spray with them alone. Thus, it could be concluded that spraying Vicia faba, L. plants grown under sandy soil conditions with the combination among potassium, zinc and Artemisia inculta extract at different concentration was the superior treatment for improving flowering, setting and yield quality characters.

\section{Anatomical feature}

\section{a- Stem anatomy}

Table (5) and Fig 1 represent the anatomical features of stem of vicia faba, L. plants foliar sprayed by different concentrations of potassium, zinc and Artemisia inculta extract. Spraying vicia faba, L. plants by single treatments of potassium ( 0.3 or $0.6 \% \mathrm{~K}_{2} \mathrm{O}$ ), Zn (100 or $200 \mathrm{ppm}$ ) and Artemisia inculta extract (5 or $10 \mathrm{~cm}^{3} / \mathrm{L}$ ) significantly increased stem diameter, pith diameter cortex thickness, number of vascular bundle/section and average of vascular bundle thickness more than control treatments (sprayed water). While spraying plants with potassium at any concentrations $\left(0.3\right.$ or $0.6 \% \mathrm{~K}_{2} \mathrm{O}$ ) gave the highest values of stem diameter, pith diameter, number of vascular bundle/section and average of vascular bundle thickness comparatively to those sprayed with zinc and Artemisia inculta extract at different concentrations. Meanwhile, spraying plants with zinc at rate $100 \mathrm{ppm}$ recorded the highest value of cortex thickness as compared to other spraying and control.

As for as, the effect of interaction between potassium, zinc and Artemisia inculta extract on some anatomical structure are shown in Table 5 and Fig. 1, it is obvious from the data that all interaction treatments were superior than the control treatment 
in all anatomical structure study (stem diameter, pith diameter cortex thickness, number of vascular bundle/section and average of vascular bundle thickness) and also than the individual treatments in some anatomical structure (pith diameter, number of vascular bundle/section and average of vascular bundle thickness). In general, spraying Vicia faba, L. plants with single solution or combination of potassium, zinc and Artemisia inculta extract at all different concentration showed significantly increase all anatomical structure study.

\section{b- Leaf anatomy}

The data which recorded in Table (6) and Fig.2 represent the anatomical measurements of leaf dimensions (midvien thickness, midvein width, midvein vascular bundle thickness, midvein vascular bundle width, blade thickness, spongy tissue thickness and number of xylem arms) of Vicia faba, L. plants foliar sprayed with different concentrations of potassium, zinc and Artemisia inculta extract. Generally, the most of spray treatments (single solution or all combinations) increased midvein thickness, midvein width, midvein vascular bundle thickness, midvein vascular bundle width, blade thickness, spongy tissue thickness and number of xylem arms as compared to control treatment (spray water).

Plants sprayed with $0.3 \% \mathrm{~K}_{2} \mathrm{O}+200 \mathrm{ppm}$ zinc $+10 \mathrm{~cm}^{3}$ Artemisia inculta extract/liter gave the highest values of midvien thickness, blade thickness and spongy tissue thickness than other treatments (single and combinations). On the other side, plants sprayed with $0.3 \% \mathrm{~K}_{2} \mathrm{O}+200 \mathrm{ppm}$ zinc $+5 \mathrm{~cm}^{3}$ Artemisia inculta extract/liter recorded the highest values of midvein vascular bundle thickness and midvein vascular bundle width than other treatments. Plants sprayed with $0.6 \% \mathrm{~K}_{2} \mathrm{O}+200$ ppm zinc $+5 \mathrm{~cm}^{3}$ Artemisia inculta extract/liter showed the highest value of midvein width than other treatments, but plants sprayed with $0.6 \% \mathrm{~K}_{2} \mathrm{O}+200 \mathrm{ppm}$ zinc +10 $\mathrm{cm}^{3}$ Artemisia inculta extract/liter gave the best value of number of xylem arms more than other treatments.

The present results indicated that Artemisia inculta extract combined with $\mathrm{K}$ and $\mathrm{Zn}$ has positive effects on stem and leaf anatomical features due to the antioxidant constituents and organic acids in Artemisia inculta extract, role of potassium in regulating plant water relations and role of $\mathrm{Zn}$ which acts as co-factors for many enzymes including in the different metabolic processes and synthesis of auxins, which stimulate cell division and expansion (Mohamed and Saif El-Yazal, 2004).

Mohamed (2005) found that spray vicia faba, L. plants with fertilizers containing potassium increased section diameter and number of xylem vessels and their diameter, but decreased pith dimensions.

\section{Conclusion}

It could be concluded that spraying Vicia faba, L. plants grown under sandy soil conditions with the combinations among potassium, zinc and Artemisia inculta 
extract at different concentrations under study was the superior treatment for improving flowering, setting and yield quality characters.

Table 2. Effect of spraying with potassium, zinc and Artemisia inculta extract on vegetative growth of Vicia faba, L. plants throughout seasons 2006 2007 and $2007-2008$.

\begin{tabular}{|c|c|c|c|c|c|c|c|c|}
\hline \multirow{2}{*}{$\begin{array}{l}\text { Characters } \\
\text { Treatments }\end{array}$} & \multicolumn{2}{|c|}{ Plant height (cm) } & \multicolumn{2}{|c|}{ No of leaves/plant } & \multicolumn{2}{|c|}{$\begin{array}{c}\text { No of } \\
\text { branches/plant }\end{array}$} & \multicolumn{2}{|c|}{ Dry matter/plant $(\mathrm{g})$} \\
\hline & $\begin{array}{c}\text { First } \\
\text { season }\end{array}$ & $\begin{array}{l}\text { Second } \\
\text { season }\end{array}$ & $\begin{array}{c}\text { First } \\
\text { season }\end{array}$ & $\begin{array}{l}\text { Second } \\
\text { season }\end{array}$ & $\begin{array}{c}\text { First } \\
\text { season }\end{array}$ & $\begin{array}{l}\text { Second } \\
\text { season }\end{array}$ & $\begin{array}{c}\text { First } \\
\text { season }\end{array}$ & $\begin{array}{l}\text { Second } \\
\text { season }\end{array}$ \\
\hline 1 & $80.68^{\mathrm{a}}$ & $75.44^{\mathrm{a}}$ & $40.54^{\mathrm{a}}$ & $40.05^{a}$ & $2.60^{\mathrm{a}}$ & $2.87^{\mathrm{a}}$ & $84.51^{\mathrm{a}}$ & $77.60^{\mathrm{a}}$ \\
\hline 2 & $87.65^{\mathrm{a}}$ & $83.05^{\mathrm{ab}}$ & $44.17^{\mathrm{ab}}$ & $43.25^{\mathrm{ab}}$ & $2.88^{\mathrm{a}}$ & $2.79^{\mathrm{a}}$ & $95.42^{\mathrm{ab}}$ & $92.86^{\mathrm{ab}}$ \\
\hline 3 & $91.45^{\mathrm{a}}$ & $95.37^{\mathrm{bc}}$ & $45.29^{\mathrm{ab}}$ & $41.72^{\mathrm{ab}}$ & $2.71^{a}$ & $2.53^{\mathrm{a}}$ & $105.94^{\mathrm{bc}}$ & $99.59^{\mathrm{bc}}$ \\
\hline 4 & $106.83^{\text {cd }}$ & $112.65^{\mathrm{cd}}$ & $48.47^{b}$ & $52.67^{b c}$ & $3.07^{\mathrm{a}}$ & $2.57^{\mathrm{a}}$ & $116.41^{\mathrm{cd}}$ & $109.27^{\mathrm{bcd}}$ \\
\hline 5 & $110.73^{\mathrm{cd}}$ & $114.70^{d}$ & $54.83^{c}$ & $53.41^{b c}$ & $3.00^{\mathrm{a}}$ & $2.80^{\mathrm{a}}$ & $119.57^{\mathrm{cd}}$ & $121.72^{d}$ \\
\hline 6 & $93.89^{\mathrm{abc}}$ & $99.60^{c}$ & $47.52^{\mathrm{ab}}$ & $44.37^{\mathrm{ab}}$ & $3.06^{\mathrm{a}}$ & $3.29^{\mathrm{a}}$ & $108.36^{\mathrm{bc}}$ & $111.36^{\mathrm{bcd}}$ \\
\hline 7 & $98.72^{\mathrm{bc}}$ & $96.71^{b c}$ & $44.59^{a}$ & $45.26^{a}$ & $2.82^{\mathrm{a}}$ & $3.47^{\mathrm{a}}$ & $108.91^{b c}$ & $102.97^{b c}$ \\
\hline 8 & $117.13^{\text {de }}$ & $121.90^{\mathrm{e}}$ & $55.87^{c}$ & $53.76^{\mathrm{bc}}$ & $2.87^{\mathrm{a}}$ & $3.04^{\mathrm{a}}$ & $122.55^{d}$ & $119.85^{c d}$ \\
\hline 9 & $125.77 \mathrm{e}$ & $124.80^{\mathrm{e}}$ & $60.92^{\mathrm{cd}}$ & $63.60^{c d}$ & $2.62^{\mathrm{a}}$ & $2.76^{\mathrm{a}}$ & $124.15^{d}$ & $121.93^{d}$ \\
\hline 10 & $123.60^{\mathrm{e}}$ & $124.26^{\mathrm{e}}$ & $64.78^{\mathrm{d}}$ & $60.34^{\mathrm{cd}}$ & $3.01^{\mathrm{a}}$ & $2.46^{\mathrm{a}}$ & $122.18^{\mathrm{d}}$ & $124.61^{d}$ \\
\hline 11 & $128.47^{e}$ & $124.13^{\mathrm{e}}$ & $69.68^{e}$ & $59.61^{c d}$ & $3.25^{\mathrm{a}}$ & $2.86^{\mathrm{a}}$ & $124.15^{\mathrm{d}}$ & $125.06^{d}$ \\
\hline 12 & $124.93^{e}$ & $122.97^{e}$ & $62.37^{d}$ & $61.64^{d}$ & $3.27^{\mathrm{a}}$ & $3.17^{\mathrm{a}}$ & $123.23^{d}$ & $122.71^{d}$ \\
\hline 13 & $126.43^{\mathrm{e}}$ & $126.10^{\mathrm{e}}$ & $72.46^{\mathrm{e}}$ & $68.65^{d}$ & $3.08^{\mathrm{a}}$ & $3.37^{\mathrm{a}}$ & $128.92^{\mathrm{d}}$ & $126.78^{d}$ \\
\hline 14 & $123.50^{\mathrm{e}}$ & $123.37^{e}$ & $65.93^{\mathrm{de}}$ & $68.64^{d}$ & $3.16^{\mathrm{a}}$ & $2.92^{\mathrm{a}}$ & $122.74^{d}$ & $124.10^{d}$ \\
\hline 15 & $124.50^{\mathrm{e}}$ & $123.87^{e}$ & $72.02^{\mathrm{e}}$ & $69.42^{\mathrm{d}}$ & $2.89^{\mathrm{a}}$ & $3.26^{\mathrm{a}}$ & $127.72^{d}$ & $129.71^{d}$ \\
\hline
\end{tabular}

$\begin{array}{lll}\text { 1. Control (sprayed water) } & \text { 2. Sprayed with zinc at rate } 100 \mathrm{ppm} & 3 \text {. Sprayed with zinc at rate } 200 \mathrm{ppm}\end{array}$

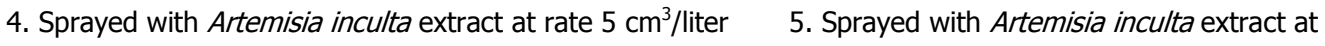
rate $10 \mathrm{~cm}^{3} /$ liter $\quad 6$. Sprayed with $\mathrm{K}_{2} \mathrm{O}$ at rate $0.3 \% \quad$ 7. Sprayed with $\mathrm{K}_{2} \mathrm{O}$ at rate $0.6 \%$

8. Sprayed with $100 \mathrm{ppm}$ zinc $+0.3 \% \mathrm{~K}_{2} \mathrm{O}+5 \mathrm{~cm}^{3}$ Artemisia inculta extract/liter

9. Sprayed with $100 \mathrm{ppm}$ zinc $+0.3 \% \mathrm{~K}_{2} \mathrm{O}+10 \mathrm{~cm}^{3}$ Artemisia inculta extract/liter

10. Sprayed with $100 \mathrm{ppm}$ zinc $+0.6 \% \mathrm{~K}_{2} \mathrm{O}+5 \mathrm{~cm}^{3}$ Artemisia inculta extract/liter

11. Sprayed with 100 ppm zinc $+0.6 \% \mathrm{~K}_{2} \mathrm{O}+10 \mathrm{~cm}^{3}$ Artemisia inculta extract/liter

12. Sprayed with $200 \mathrm{ppm}$ zinc $+0.3 \% \mathrm{~K}_{2} \mathrm{O}+5 \mathrm{~cm}^{3}$ Artemisia inculta extract/liter

13. Sprayed with $200 \mathrm{ppm}$ zinc $+0.3 \% \mathrm{~K}_{2} \mathrm{O}+10 \mathrm{~cm}^{3}$ Artemisia inculta extract/liter

14. Sprayed with $200 \mathrm{ppm}$ zinc $+0.6 \% \mathrm{~K}_{2} \mathrm{O}+5 \mathrm{~cm}^{3}$ Artemisia inculta extract/liter

15. Sprayed with $200 \mathrm{ppm}$ zinc $+0.6 \% \mathrm{~K}_{2} \mathrm{O}+10 \mathrm{~cm}^{3}$ Artemisia inculta extract/liter 
Table 3 Effect of spraying with potassium, zinc and Artemisia inculta extract on pods physical characters and yield of Vicia faba, L. plants throughout seasons 2006 - 2007 and 2007 - 2008.

\begin{tabular}{|c|c|c|c|c|c|c|c|c|}
\hline \multirow{2}{*}{$\begin{array}{l}\text { Characters } \\
\text { Treatments }\end{array}$} & \multicolumn{2}{|c|}{ Pod length $(\mathrm{cm})$} & \multicolumn{2}{|c|}{ Pod weight (g) } & \multicolumn{2}{|c|}{ No of pods/plant } & \multicolumn{2}{|c|}{ Pods yield/fed (ton) } \\
\hline & $\begin{array}{c}\text { First } \\
\text { season }\end{array}$ & $\begin{array}{l}\text { Second } \\
\text { season }\end{array}$ & $\begin{array}{c}\text { First } \\
\text { season }\end{array}$ & $\begin{array}{l}\text { Second } \\
\text { season }\end{array}$ & $\begin{array}{c}\text { First } \\
\text { season }\end{array}$ & $\begin{array}{l}\text { Second } \\
\text { season }\end{array}$ & $\begin{array}{c}\text { First } \\
\text { season }\end{array}$ & $\begin{array}{l}\text { Second } \\
\text { season }\end{array}$ \\
\hline 1 & $8.05^{\mathrm{a}}$ & $7.49^{\mathrm{a}}$ & $69.14^{\mathrm{a}}$ & $59.40^{\mathrm{a}}$ & $6.48^{\mathrm{a}}$ & $5.70^{\mathrm{a}}$ & $3.103^{\mathrm{a}}$ & $2.955^{a}$ \\
\hline 2 & $7.67^{\mathrm{a}}$ & $7.69^{a}$ & $87.83^{\mathrm{ab}}$ & $85.01^{\mathrm{ab}}$ & $8.35^{\mathrm{ab}}$ & $8.57^{a}$ & $3.340^{\mathrm{ab}}$ & $3.360^{\mathrm{ab}}$ \\
\hline 3 & $8.66^{\mathrm{ab}}$ & $8.54^{\mathrm{a}}$ & $94.80^{\mathrm{ab}}$ & $94.37^{\mathrm{abc}}$ & $9.17^{\mathrm{abc}}$ & $9.24^{\mathrm{ab}}$ & $3.492^{\mathrm{ab}}$ & $3.608^{\mathrm{bc}}$ \\
\hline 4 & $11.60^{c}$ & $10.87^{b}$ & $114.91^{b c}$ & $125.54^{\mathrm{bcd}}$ & $11.66^{\mathrm{cd}}$ & $13.31^{\mathrm{cd}}$ & $3.910^{\text {cd }}$ & $3.867^{b c}$ \\
\hline 5 & $11.97^{c}$ & $12.27^{\mathrm{bc}}$ & $131.97^{\mathrm{cd}}$ & $132.20^{\text {cd }}$ & $12.73^{d}$ & $12.90^{\text {bcd }}$ & $4.178^{\text {cde }}$ & $4.043^{\mathrm{cd}}$ \\
\hline 6 & $9.78^{\mathrm{bc}}$ & $10.80^{\mathrm{b}}$ & $100.63^{\mathrm{ab}}$ & $124.10^{\mathrm{bcd}}$ & $9.50^{\mathrm{abc}}$ & $10.00^{\mathrm{abc}}$ & $3.705^{\mathrm{bc}}$ & $3.625^{\mathrm{bc}}$ \\
\hline 7 & $10.52^{\mathrm{c}}$ & $10.90^{\mathrm{b}}$ & $110.78^{\mathrm{bc}}$ & $106.95^{\mathrm{bc}}$ & $11.09^{\mathrm{bcd}}$ & $10.67^{\mathrm{abc}}$ & $3.806^{\mathrm{bc}}$ & $3.819^{\mathrm{bc}}$ \\
\hline 8 & $11.63^{c}$ & $12.07^{\mathrm{bc}}$ & $146.65^{\text {de }}$ & $139.08^{\text {de }}$ & $14.17^{\text {de }}$ & $14.13^{\text {de }}$ & $4.289^{\mathrm{def}}$ & $4.319^{\text {de }}$ \\
\hline 9 & $12.03^{c}$ & $12.37^{\mathrm{bc}}$ & $149.92^{\text {de }}$ & $158.49^{\text {def }}$ & $14.60^{\mathrm{de}}$ & $15.96^{\mathrm{de}}$ & $4.444^{\mathrm{ef}}$ & $4.311^{\text {de }}$ \\
\hline 10 & $12.03^{c}$ & $11.27^{\mathrm{bc}}$ & $149.14^{\text {de }}$ & $153.29^{\text {def }}$ & $14.53^{\mathrm{de}}$ & $14.78^{\mathrm{de}}$ & $4.374^{e f}$ & $4.348^{\mathrm{de}}$ \\
\hline 11 & $11.90^{c}$ & $11.87^{\mathrm{bc}}$ & $175.28^{f}$ & $171.92^{\mathrm{ef}}$ & $16.65^{\mathrm{e}}$ & $16.77^{\text {de }}$ & $4.642^{\mathrm{fg}}$ & $4.504^{d}$ \\
\hline 12 & $11.90^{c}$ & $12.77^{c}$ & $167.30^{\text {ef }}$ & $173.50^{\text {ef }}$ & $15.75^{e}$ & $16.95^{\mathrm{e}}$ & $4.630^{\mathrm{fg}}$ & $4.671^{d}$ \\
\hline 13 & $12.30^{c}$ & $12.17^{\mathrm{bc}}$ & $192.08^{f}$ & $192.44^{f}$ & $18.53^{\mathrm{e}}$ & $17.90^{\mathrm{e}}$ & $4.834^{9}$ & $4.698^{\mathrm{e}}$ \\
\hline 14 & $12.13^{c}$ & $12.63^{c}$ & $176.25^{\mathrm{ef}}$ & $173.85^{e}$ & $16.67^{e}$ & $14.57^{\mathrm{de}}$ & $4.739^{9}$ & $4.751^{\mathrm{e}}$ \\
\hline 15 & $11.63^{c}$ & $12.20^{\mathrm{bc}}$ & $193.82^{f}$ & $168.58^{\mathrm{ef}}$ & $17.98^{\mathrm{e}}$ & $18.21^{\mathrm{e}}$ & $4.873^{9}$ & $4.754^{\mathrm{e}}$ \\
\hline
\end{tabular}

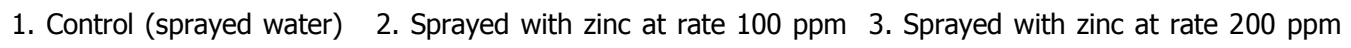

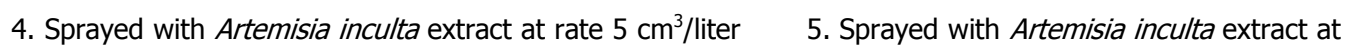
rate $10 \mathrm{~cm}^{3} /$ liter $\quad$ 6. Sprayed with $\mathrm{K}_{2} \mathrm{O}$ at rate $0.3 \% \quad$ 7. Sprayed with $\mathrm{K}_{2} \mathrm{O}$ at rate $0.6 \%$

8. Sprayed with $100 \mathrm{ppm}$ zinc $+0.3 \% \mathrm{~K}_{2} \mathrm{O}+5 \mathrm{~cm}^{3}$ Artemisia inculta extract/liter

9. Sprayed with $100 \mathrm{ppm}$ zinc $+0.3 \% \mathrm{~K}_{2} \mathrm{O}+10 \mathrm{~cm}^{3}$ Artemisia inculta extract/liter

10. Sprayed with $100 \mathrm{ppm}$ zinc $+0.6 \% \mathrm{~K}_{2} \mathrm{O}+5 \mathrm{~cm}^{3}$ Artemisia inculta extract/liter

11. Sprayed with $100 \mathrm{ppm}$ zinc $+0.6 \% \mathrm{~K}_{2} \mathrm{O}+10 \mathrm{~cm}^{3}$ Artemisia inculta extract/liter

12. Sprayed with $200 \mathrm{ppm}$ zinc $+0.3 \% \mathrm{~K}_{2} \mathrm{O}+5 \mathrm{~cm}^{3}$ Artemisia inculta extract/liter

13. Sprayed with $200 \mathrm{ppm}$ zinc $+0.3 \% \mathrm{~K}_{2} \mathrm{O}+10 \mathrm{~cm}^{3}$ Artemisia inculta extract/liter

14. Sprayed with $200 \mathrm{ppm}$ zinc $+0.6 \% \mathrm{~K}_{2} \mathrm{O}+5 \mathrm{~cm}^{3}$ Artemisia inculta extract/liter

15. Sprayed with $200 \mathrm{ppm}$ zinc $+0.6 \% \mathrm{~K}_{2} \mathrm{O}+10 \mathrm{~cm}^{3}$ Artemisia inculta extract/liter 
Table 4. Effect of spraying with potassium, zinc and Artemisia inculta extract on some flowering, setting and yield quality characters of Vicia faba, L. plants throughout seasons 2006 - 2007 and 2007 - 2008.

\begin{tabular}{|c|c|c|c|c|c|c|c|c|c|c|}
\hline \multirow{2}{*}{$\begin{array}{l}\text { Characters } \\
\text { Treatments }\end{array}$} & \multicolumn{2}{|c|}{ No of flowers/plant } & \multicolumn{2}{|c|}{ Setting percentage } & \multicolumn{2}{|c|}{$\begin{array}{c}\text { No of } \\
\text { seeds/pod }\end{array}$} & \multicolumn{2}{|c|}{$\begin{array}{c}\text { Net weight of seeds } \\
\% \\
\end{array}$} & \multicolumn{2}{|c|}{$\begin{array}{r}\text { Height of } 1^{\text {st }} \text { pod } \\
\text { on main stem }(\mathrm{cm}) \\
\end{array}$} \\
\hline & $\begin{array}{c}\text { First } \\
\text { season }\end{array}$ & $\begin{array}{l}\text { Second } \\
\text { season }\end{array}$ & $\begin{array}{c}\text { First } \\
\text { season }\end{array}$ & $\begin{array}{l}\text { Second } \\
\text { season }\end{array}$ & $\begin{array}{c}\text { First } \\
\text { season }\end{array}$ & $\begin{array}{l}\text { Second } \\
\text { season }\end{array}$ & $\begin{array}{c}\text { First } \\
\text { season }\end{array}$ & $\begin{array}{l}\text { Second } \\
\text { season }\end{array}$ & $\begin{array}{c}\text { First } \\
\text { season }\end{array}$ & $\begin{array}{l}\text { Second } \\
\text { season }\end{array}$ \\
\hline 1 & $17.76 a$ & $17.07 a$ & $36.30 a$ & $35.32 a$ & $4.03 a$ & $4.30 \mathrm{a}$ & $49.80 a$ & 49.98a & $36.17 e$ & $37.62 d$ \\
\hline 2 & 19.15ab & 18.51ab & 43.65ab & 46.38ab & $4.56 a b$ & $4.42 a$ & 52.69ab & 53.17ab & $27.58 \mathrm{~d}$ & $26.58 \mathrm{c}$ \\
\hline 3 & $18.18 a$ & $18.33 a$ & 50.58ab & $50.40 a b c$ & $5.30 \mathrm{bc}$ & 5.02ab & 53.17ab & 54.23ab & $25.53 \mathrm{~cd}$ & $24.38 \mathrm{c}$ \\
\hline 4 & $20.32 \mathrm{ab}$ & 19.69abc & 57.43bcde & $67.75 b c$ & $5.23 b c$ & $5.10 a b$ & $59.53 a$ & 57.69abc & $22.54 b c$ & $23.36 \mathrm{bc}$ \\
\hline 5 & 21.02abc & 20.95abc & $60.66 \mathrm{bcde}$ & $61.85 \mathrm{bc}$ & $5.43 \mathrm{bc}$ & 4.86ab & 61.47abc & $60.49 \mathrm{bcd}$ & 18.91ab & $17.48 a$ \\
\hline 6 & 19.91ab & 19.00abc & 46.99abc & $53.24 a b c$ & $4.80 a$ & 5.28abc & $66.21 b c$ & $65.71 \mathrm{~cd}$ & $25.52 \mathrm{~cd}$ & $26.43 c$ \\
\hline 7 & $21.26 a b c$ & 18.74ab & 52.24abcd & 56.93abc & $4.96 a$ & 5.32abc & $66.34 \mathrm{bc}$ & $70.57 d$ & $24.85 c$ & $24.95 c$ \\
\hline 8 & $23.27 \mathrm{bc}$ & $23.13 b c d$ & 61.09bcde & 61.31abc & $5.99 c$ & $5.70 b c$ & 64.90abc & $68.61 \mathrm{~cd}$ & 18.14ab & $19.14 a b$ \\
\hline 9 & $24.54 b c$ & $23.93 \mathrm{~cd}$ & 59.99 bcde & $67.11 b c$ & $5.94 c$ & $5.96 b c$ & $69.38 c$ & $67.41 \mathrm{~cd}$ & 18.84ab & 18.64ab \\
\hline 10 & $21.21 a b c$ & $21.14 a b c$ & 69.13de & $70.85 b c$ & $5.89 \mathrm{c}$ & $5.92 b c$ & $72.41 \mathrm{c}$ & $67.70 \mathrm{~cd}$ & $16.91 a$ & $16.76 a b$ \\
\hline 11 & $20.34 a b$ & $21.60 \mathrm{abc}$ & $83.18 \mathrm{e}$ & $77.95 \mathrm{c}$ & $5.89 \mathrm{c}$ & $6.36 c$ & $75.38 \mathrm{c}$ & $73.05 d$ & 18.93ab & $16.92 a$ \\
\hline 12 & 20.77ab & $25.61 \mathrm{~cd}$ & $77.15 \mathrm{e}$ & $64.61 b c$ & $6.07 c$ & $6.06 \mathrm{bc}$ & $70.74 c$ & $68.79 \mathrm{~cd}$ & 17.36ab & $17.43 a$ \\
\hline 13 & $26.02 c$ & $24.76 \mathrm{~cd}$ & $71.66 \mathrm{e}$ & $73.33 c$ & $6.07 c$ & $6.33 b c$ & $71.96 c$ & $72.48 d$ & $15.49 a$ & $18.02 \mathrm{ab}$ \\
\hline 14 & $26.69 c$ & $26.40 \mathrm{~d}$ & 63.11cde & $55.58 a b c$ & $6.02 c$ & $5.74 b c$ & $72.37 c$ & 77.47e & 17.15ab & $16.61 a$ \\
\hline 15 & $26.22 c$ & $25.90 \mathrm{~cd}$ & 68.83de & $70.31 \mathrm{c}$ & $5.78 c$ & $5.74 b c$ & $62.60 \mathrm{abc}$ & $78.31 \mathrm{e}$ & 17.41ab & $17.09 a$ \\
\hline
\end{tabular}

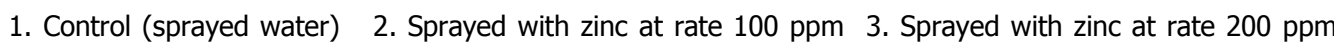
4. Sprayed with Artemisia inculta extract at rate $5 \mathrm{~cm}^{3} /$ liter $\quad 5$. Sprayed with Artemisia inculta extract at rate $10 \mathrm{~cm}^{3} /$ liter $\quad 6$. Sprayed with $\mathrm{K}_{2} \mathrm{O}$ at rate $0.3 \% \quad$ 7. Sprayed with $\mathrm{K}_{2} \mathrm{O}$ at rate $0.6 \%$ 8. Sprayed with $100 \mathrm{ppm}$ zinc $+0.3 \% \mathrm{~K}_{2} \mathrm{O}+5 \mathrm{~cm}^{3}$ Artemisia inculta extract/liter 9. Sprayed with $100 \mathrm{ppm}$ zinc $+0.3 \% \mathrm{~K}_{2} \mathrm{O}+10 \mathrm{~cm}^{3}$ Artemisia inculta extract/liter 10. Sprayed with $100 \mathrm{ppm}$ zinc $+0.6 \% \mathrm{~K}_{2} \mathrm{O}+5 \mathrm{~cm}^{3}$ Artemisia inculta extract/liter 11. Sprayed with $100 \mathrm{ppm}$ zinc $+0.6 \% \mathrm{~K}_{2} \mathrm{O}+10 \mathrm{~cm}^{3}$ Artemisia inculta extract/liter

12. Sprayed with $200 \mathrm{ppm}$ zinc $+0.3 \% \mathrm{~K}_{2} \mathrm{O}+5 \mathrm{~cm}^{3}$ Artemisia inculta extract/liter

13. Sprayed with $200 \mathrm{ppm}$ zinc $+0.3 \% \mathrm{~K}_{2} \mathrm{O}+10 \mathrm{~cm}^{3}$ Artemisia inculta extract/liter

14. Sprayed with $200 \mathrm{ppm}$ zinc $+0.6 \% \mathrm{~K}_{2} \mathrm{O}+5 \mathrm{~cm}^{3}$ Artemisia inculta extract/liter 15. Sprayed with $200 \mathrm{ppm}$ zinc $+0.6 \% \mathrm{~K}_{2} \mathrm{O}+10 \mathrm{~cm}^{3}$ Artemisia inculta extract/liter 
Table 5. Anatomical characteristics of vicia faba, L. stem sprayed with potassium, zinc and Artemisia inculta extract throughout seasons 2006 - 2007 and 2007 2008.

\begin{tabular}{|c|c|c|c|c|c|}
\hline $\begin{array}{l}\text { Characters } \\
\text { Treatments }\end{array}$ & $\begin{array}{c}\text { Stem diameter } \\
(\mu)\end{array}$ & $\begin{array}{l}\text { Pith diameter } \\
(\mu)\end{array}$ & $\begin{array}{c}\text { Cortex } \\
\text { thickness }(\mu)\end{array}$ & $\begin{array}{c}\text { No of vascular } \\
\text { bundle/ } \\
\text { section }\end{array}$ & $\begin{array}{c}\text { Vascular } \\
\text { bundle } \\
\text { thickness }(\mu)\end{array}$ \\
\hline 1 & 5008 & 2291 & 252 & 20 & 233 \\
\hline 2 & 5418 & 2814 & 355 & 24 & 285 \\
\hline 3 & 6457 & 3446 & 282 & 24 & 280 \\
\hline 4 & 6564 & 3575 & 268 & 24 & 329 \\
\hline 5 & 5974 & 2962 & 289 & 28 & 332 \\
\hline 6 & 6359 & 2866 & 274 & 28 & 377 \\
\hline 7 & 6389 & 4137 & 316 & 28 & 300 \\
\hline 8 & 5469 & 3331 & 314 & 28 & 378 \\
\hline 9 & 5239 & 3455 & 302 & 28 & 318 \\
\hline 10 & 6200 & 3280 & 280 & 24 & 324 \\
\hline 11 & 6444 & 3883 & 313 & 28 & 437 \\
\hline 12 & 5394 & 3506 & 332 & 48 & 322 \\
\hline 13 & 6222 & 3856 & 262 & 32 & 395 \\
\hline 14 & 6540 & 3986 & 333 & 28 & 437 \\
\hline 15 & 6270 & 4312 & 311 & 52 & 352 \\
\hline
\end{tabular}

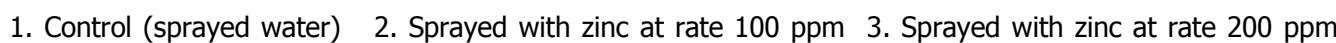
4. Sprayed with Artemisia inculta extract at rate $5 \mathrm{~cm}^{3} /$ liter 5. Sprayed with Artemisia inculta extract at rate $10 \mathrm{~cm}^{3} /$ liter 6. Sprayed with $\mathrm{K}_{2} \mathrm{O}$ at rate $0.3 \%$ 7. Sprayed with $\mathrm{K}_{2} \mathrm{O}$ at rate $0.6 \%$

8. Sprayed with $100 \mathrm{ppm}$ zinc $+0.3 \% \mathrm{~K}_{2} \mathrm{O}+5 \mathrm{~cm}^{3}$ Artemisia inculta extract/liter

9. Sprayed with $100 \mathrm{ppm}$ zinc $+0.3 \% \mathrm{~K}_{2} \mathrm{O}+10 \mathrm{~cm}^{3}$ Artemisia inculta extract/liter

10. Sprayed with $100 \mathrm{ppm}$ zinc $+0.6 \% \mathrm{~K}_{2} \mathrm{O}+5 \mathrm{~cm}^{3}$ Artemisia inculta extract/liter

11. Sprayed with $100 \mathrm{ppm}$ zinc $+0.6 \% \mathrm{~K}_{2} \mathrm{O}+10 \mathrm{~cm}^{3}$ Artemisia inculta extract/liter

12. Sprayed with $200 \mathrm{ppm}$ zinc $+0.3 \% \mathrm{~K}_{2} \mathrm{O}+5 \mathrm{~cm}^{3}$ Artemisia inculta extract/liter

13. Sprayed with $200 \mathrm{ppm}$ zinc $+0.3 \% \mathrm{~K}_{2} \mathrm{O}+10 \mathrm{~cm}^{3}$ Artemisia inculta extract/liter

14. Sprayed with $200 \mathrm{ppm}$ zinc $+0.6 \% \mathrm{~K}_{2} \mathrm{O}+5 \mathrm{~cm}^{3}$ Artemisia inculta extract/liter

15. Sprayed with $200 \mathrm{ppm}$ zinc $+0.6 \% \mathrm{~K}_{2} \mathrm{O}+10 \mathrm{~cm}^{3}$ Artemisia inculta extract/liter 
Table 6. Anatomical characteristics of vicia faba, L. leaf sprayed with potassium, zinc and Artemisia inculta extract throughout seasons 2006 - 2007 and 2007 $-2008$.

\begin{tabular}{|c|c|c|c|c|c|c|c|}
\hline $\begin{array}{l}\text { Characters } \\
\text { Treatments }\end{array}$ & $\begin{array}{c}\text { Midvien } \\
\text { thickness } \\
(\mu)\end{array}$ & $\begin{array}{l}\text { Midvein } \\
\text { width } \\
(\mu)\end{array}$ & $\begin{array}{l}\text { Midvein } \\
\text { vascular } \\
\text { bundle } \\
\text { thick. }(\mu)\end{array}$ & $\begin{array}{c}\text { Midvein } \\
\text { vascular } \\
\text { bundle } \\
\text { width } \\
(\mu)\end{array}$ & $\begin{array}{c}\text { Blade } \\
\text { thick } \\
(\mu)\end{array}$ & $\begin{array}{c}\text { Spongy } \\
\text { tissue } \\
\text { thickness } \\
\quad(\mu)\end{array}$ & $\begin{array}{l}\text { No. of } \\
\text { xylem } \\
\text { arms }\end{array}$ \\
\hline 1 & 774 & 823 & 202 & 115 & 381 & 158 & 3 \\
\hline 2 & 864 & 944 & 321 & 171 & 351 & 180 & 3 \\
\hline 3 & 1045 & 857 & 223 & 173 & 475 & 291 & 4 \\
\hline 4 & 959 & 831 & 248 & 132 & 492 & 331 & 3 \\
\hline 5 & 965 & 958 & 210 & 201 & 570 & 285 & 5 \\
\hline 6 & 978 & 902 & 271 & 178 & 544 & 290 & 5 \\
\hline 7 & 1157 & 989 & 262 & 175 & 427 & 246 & 4 \\
\hline 8 & 1046 & 955 & 382 & 98 & 505 & 300 & 8 \\
\hline 9 & 795 & 1007 & 399 & 116 & 454 & 241 & 4 \\
\hline 10 & 1010 & 943 & 363 & 175 & 510 & 268 & 4 \\
\hline 11 & 1013 & 1159 & 316 & 175 & 483 & 274 & 7 \\
\hline 12 & 969 & 1086 & 421 & 278 & 513 & 257 & 6 \\
\hline 13 & 1253 & 1230 & 359 & 241 & 714 & 457 & 5 \\
\hline 14 & 988 & 1321 & 350 & 210 & 500 & 356 & 6 \\
\hline 15 & 1051 & 976 & 314 & 256 & 640 & 401 & 7 \\
\hline
\end{tabular}

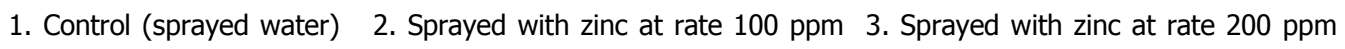
4. Sprayed with Artemisia inculta extract at rate $5 \mathrm{~cm}^{3} /$ liter

5. Sprayed with Artemisia inculta extract at rate $10 \mathrm{~cm}^{3} /$ liter

6. Sprayed with $\mathrm{K}_{2} \mathrm{O}$ at rate $0.3 \%$

7. Sprayed with $\mathrm{K}_{2} \mathrm{O}$ at rate $0.6 \%$

8. Sprayed with $100 \mathrm{ppm}$ zinc $+0.3 \% \mathrm{~K}_{2} \mathrm{O}+5 \mathrm{~cm}^{3}$ Artemisia inculta extract/liter

9. Sprayed with $100 \mathrm{ppm}$ zinc $+0.3 \% \mathrm{~K}_{2} \mathrm{O}+10 \mathrm{~cm}^{3}$ Artemisia inculta extract/liter

10. Sprayed with $100 \mathrm{ppm}$ zinc $+0.6 \% \mathrm{~K}_{2} \mathrm{O}+5 \mathrm{~cm}^{3}$ Artemisia inculta extract/liter

11. Sprayed with $100 \mathrm{ppm}$ zinc $+0.6 \% \mathrm{~K}_{2} \mathrm{O}+10 \mathrm{~cm}^{3}$ Artemisia inculta extract/liter

12. Sprayed with $200 \mathrm{ppm}$ zinc $+0.3 \% \mathrm{~K}_{2} \mathrm{O}+5 \mathrm{~cm}^{3}$ Artemisia inculta extract/liter

13. Sprayed with $200 \mathrm{ppm}$ zinc $+0.3 \% \mathrm{~K}_{2} \mathrm{O}+10 \mathrm{~cm}^{3}$ Artemisia inculta extract/liter

14. Sprayed with $200 \mathrm{ppm}$ zinc $+0.6 \% \mathrm{~K}_{2} \mathrm{O}+5 \mathrm{~cm}^{3}$ Artemisia inculta extract/liter

15. Sprayed with $200 \mathrm{ppm}$ zinc $+0.6 \% \mathrm{~K}_{2} \mathrm{O}+10 \mathrm{~cm}^{3}$ Artemisia inculta extract/liter 
846 IMPACT OF SPRAYING WITH POTASSIUM, ZINC AND ARTEMISIA INCULTA EXTRACT

ON FLOWERING, SETTING AND ANATOMICAL FEATURE

OF VICIA FABA, L. PLANTS 
ALI, T.B., et al. 


\section{REFERENCES}

1. Abd Allatif, M., I. M. El - Ghareeb and Horia M. F. Hassan. 2002. Nitrogen and potassium requirements for some broad bean cultivars under newly reclaimed soil. Egyptian J. of Applied Sci., 17 (7) 310-324.

2. Abd El-Naem, G. F. 2005. Effects of three antioxidants on some chemical constituents, enzymatic browning of tomato and browning prevention by polyphenol oxidase inhibitors. Minia J. Agric. Res. Develop., 25 (5) 815-842.

3. Agwah, E. M. and H. A. Mahmoud. 1994. Effect of some nutrients, sucrose and cultivars on tomato fruit set and yield. Bulletin Fac. Agric., Cairo Univ. 45 (1): 137148.

4. Duncan, D.B. 1958. Multiple range and Multiple F test. Biometrics 11: 1- 42.

5. Fayza, M. A. Darwesh, T. B. Ali and N. M. Hassanein. 2007. Studies on some materials for improving fruit set and quality of sweet pepper grown under high temperature. J. Agric. Sci. Mansoura Univ., 32 (7) 5487-5494.

6. Gascon, A. D., C. A. Zuritz, J. A. Bustamante, L. Borbon, G. Oberti, L. Borbon, V. Martino, A. Bandoni, G. Blaak and N. Capelle. 1999. A study of different formulations of wall support systems for microencapsulation of antioxidant essential oils. Acta Horticulturae. 503, 53-58.

7. Klein, R. M., E. M. Caputo and B. A. Witterholt. 1962. The role of zinc in the growth of plant tissue cultures. American J. Botany, 49 (4): 323-327.

8. Mohamed, S.A. and Sawsan A. Saif El-Yazal. 2004. Effect of foliar spraying by some micronutrients on growth, yield, chemical constituents and anatomical structure of cotton plants (Gossypium vitifolium, L.) grown in newly reclaimed sandy soil. Ann. of Agric. Sci. Moshtohor, 42 (3) 1053-1070.

9. Mohamed, S. E. A. 2005. Phytochemcal studies on common bean (Phaseolus vulgaris L.) plants as affected by foliar fertilizer and active dry yeast under sandy soil conditions. Egypt. J. Appl. Sci., 20: 539-559.

10. Shi, G.A.n., X. F. Guo, W. TingCai, B. Q. Xue, G. A. Shi, X. F. Guo, X.C. Wu and B. Q. Xue. 1999. Antioxidation of water extract from Artemisia capillaris Thunb. in vitro. J. of Plant Resources and Environment. 8 (4) 7-10.

11. Shukla, U. C. and A. K. Mukhi. 1985. Ameliorative of zinc on maize growth (zea mays L.) under salt affected soil conditions. Plant and Soil, 87: 423-432.

12. Snedecor, G.W. and W.G. Cochran. 1980. Statistical Mathods, $7^{\text {th }}$ ed. Iowa State Univ., Press, Ames, Iowa, U.S.A.

13. Srivastava, N. K., A. Misra and S. Sharma. 1997. Effect of Zn deficiency on net photosynthetic rate, ${ }^{14} \mathrm{C}$ partitioning, and oil accumulation in leaves of peppermint. Photosynthetica. 33 (1): 71-79.

14. Sukul, N. C., S. Anirban and A. Sukul. 1999. Potentized cina reduces root-knot disease of cowpeas. Environment and Ecology. 17 (2) 269-273.

15. Willey, R. L. 1971. Microtechnique. A Laboratory Guide. Mac Millan Publishing Co. Inc. New York. 
أثر الرش بالبوتاسيوم والزنك ومستخلص الثيح البلاى على الازهار وإلعقد والتركيب

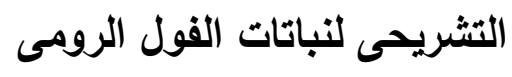

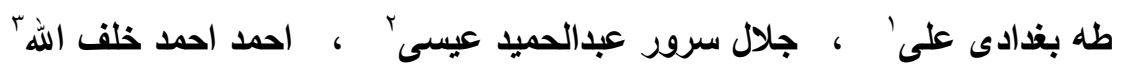
ا ـ قسم بحوث الخضر - معهد بحوث البساتين - مركز البحوث الزراعية

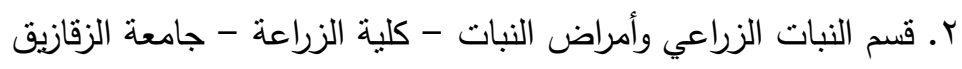

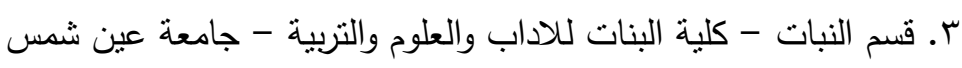

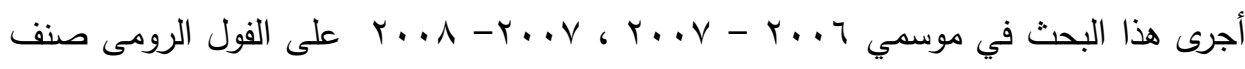

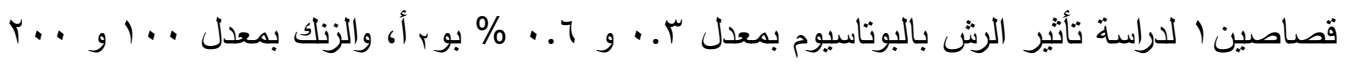

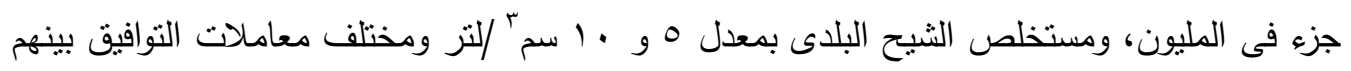
في مرحلة النمو الخضرى ونثأة الأزهار على النمو والازهار والمحصول ومكوناته والتركيب النشريحي.

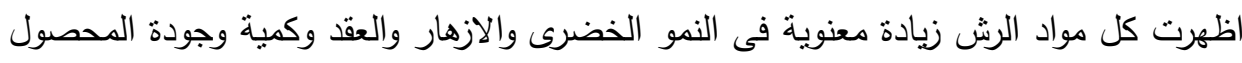
والتركيب النتريحى مقارنة بمعاملة الكنترول.

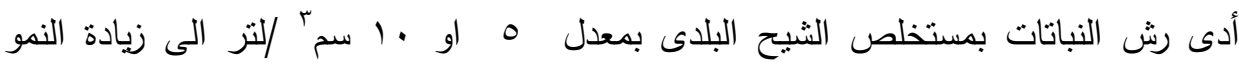

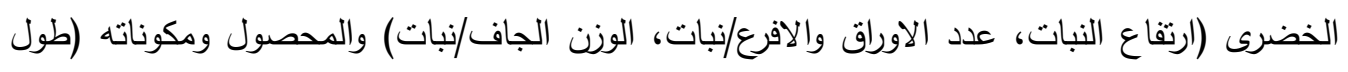

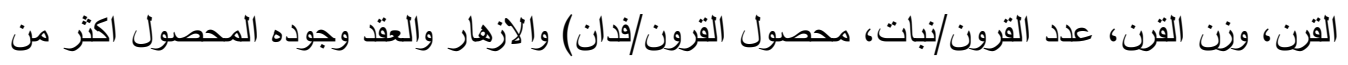

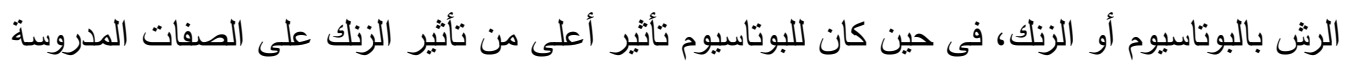

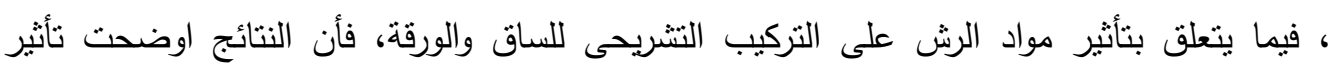
ايجابى للرش بتلك المواد على كل الصفات التى تم دراستها.

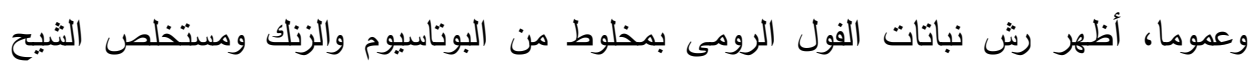
البلدى عند كل النركيزات المختلفة زيادة معنوية فى النمو الخضرى والازهار والعقد وكمية وجودة التهات المحصول والتركيب النتريحى عن الرش باى منهم منفردا او الكنترول. 